\title{
The Impact of Value Equity and Brand Equity on Loyalty: an Empirical Investigation in Retail Banking
}

\begin{abstract}
The paper deals with the problem of determining the impact of both value equity and brand equity on loyalty. The research method involved the survey conducted with retail banking customers. Limitations and future research directions are outlined.
\end{abstract}

Keywords: loyalty, customer perceived value, retail banking, Lithuania.

Straipsnyje analizuojama funkcinès vertès ir prekès ženklo vertès ịtakos lojalumui mažmeninejje bankininkysteje problematika. Mokslinei problemai tirti atliktas empirinis tyrimas mažmeninejje bankininkystejje, pateikiami tyrimo apribojimai ir tolesnio tyrimo gairès.

Raktiniai žodžiai: lojalumas, funkcinè vertè, prekès ženklo vertè, mažmeninė bankininkystė, Lietuva.

\section{Introduction}

Retail banking is mainly based on multifaceted choices that customers have to make on a daily basis. Based on intangibility of offers, there is huge competition within this market. These are the reasons why researchers have been analyzing customer loyalty in banking market heavily (Barnes \& Howlet, 1998; Beerli et al., 2004; Bergeron et al., 2008; Dibb \& Meadows, 2004; Roig et al., 2006; Bauman et al., 2006; Alrubaiee \& AlNazer, 2010). They tried to foresee both functional and brand value that might stipulate the relationship between retail customers and the bank and its impact on loyalty. Though a common understanding exists that banking market is distinguished by exceptional durability of relationship which is predetermined by banking service specifics, recent changes on the banking market have become a threat to customer loyalty (Garderner et al., 1999; Panther \& Farquhar, 2004; Foo et al., 2008).

Like many emerging economies, Lithuania's banking market has increasingly

Neringa IVANAUSKIENE - Doctor of Social Sciences, Vice-dean for Academic Affairs at ISM University of Management and Economics. Address: Arklių St. 18, Vilnius 01129, Lithuania. Tel.: 003705212 3960. E-mail: neringa.ivanauskiene@ism.lt.

Vilte AURUŠKEVIČIENE - Doctor of Social Sciences, Professor, Dean of Studies at ISM University of Management and Economics. Address: Arklių St. 18, Vilnius 01129, Lithuania. Tel.: 003705212 3960. E-mail: vilte.auruskeviciene@ism.lt. 
become challenging and influenced by privatization, market-driven consolidation and foreign bank entry. Other changes are also under way - the growth of remote banking, banking market convergence with insurance or other financial service markets. The implications of these changes should be visible in relations with retail customers as well. As earlier banks developed relationships with customers through direct contacts, the alternative service delivery systems (such as: e-banking, automatic teller machines ATMs, telephone banking) created new ways for maintaining these relationships. It is stated that the changes caused by technology development might have a bad influence on bank and customer relationship (Clarke et al., 1988; Garderner et al., 1999; Ferguson \& Hlavinka; 2007; Galetly, 2009). Furthermore, as value is a subjective construct, scientist and practitioners should better understand both functional and brand values and their impact on loyalty.

The majority of authors have been using different values; however, the most frequently analyzed ones were functional value, emotional value and social value (Sweeney \& Soutar, 2001; Roig et al., 2006; Izquierdo et al., 2006). It has been noticed that the multidimensional nature of value and the complexity of loyalty is one of the most important reasons for research limitations. Therefore, the research question has been formulated as follows: how value equity and brand equity impact on loyalty in retail banking? Thus the aim of the research is to define the impact of value equity and brand equity on loyalty in retail bank sector. To achieve the aim of this research a quantitative survey of retail customers in Lithuania was executed. Data obtained from 1111 survey questionnaire were analyzed using Partial Least Square modeling.

\section{Theoretical Considerations and Hypotheses}

\section{Value as Multidimensional Concept}

Value is a multidimensional construct (Sweeney \& Soutar, 2001; Roig et al., 2006; Huber et al., 2007). J. C. Sweeney \& G. N. Soutar (2001) proposed a PERVAL scale for measuring value where functional, emotional and social dimensions were distinguished. The value of functional component is determined by the cost, quality and utility of the product, emotional value derives from the feelings or affective states that a brand generates and the social value derives from the product's ability to enhance social self-concepts.

C. C. Izquierdo et al. (2006) in the study of Spanish bank clients divided the components of customer perceived value into three groups: (1) the functional dimension of value is created when the customer becomes aware of the financial services provider's advantages (brand credibility, quality of service, competence of the staff) and values them better than the services of their competitors; (2) the affective value occurs when the customer benefits from relations with the staff, emotional experience, self-identification with the brand and social integration; (3) the saving value is created after the customer perceives the offer as economically beneficial. Beside emotional value, social value, product value and experienced / perceived cost value some authors have also distinguished procedural value (perception of after-sales service and maintenance) and personnel value, which is created by professional skills and abilities of the service staff (Gounaris et al., 2007). Next to the functional and emotional attributes of value other authors studied rationale 
(customer's awareness of incurred cost) and risk (customer's uncertainty of the brand) attributes of value (Huber et al., 2007).

It should be noted that the majority of empirical studies are focused on the functional component that can be associated with conative and cognitive factors determining the customer's attitude and loyalty. Some authors see the convenience and price in financial services industry as cognitive factors. It is argued that a loyal customer believes that services have higher value compared to competing offers and is ready to pay more for it (Reinartz and Kumar, 2000). M. Lee \& L. F. Cunningham (2001) state, that quality is among the major factors that determine the customer's loyalty. It could be argued that the notion of customer perceived value in the studies should be attributed to the loyalty determining factors distinguished by A. Dick \& K. Basu (1994) because cognitive factors included into the research construct would better explain the functional dimension of value, whereas the analysis of emotional and conative factors would complement the notions of social and emotional dimensions. Empirical studies have confirmed that social relations between a customer and an organization act as an emotional determinant in loyalty building (Dwyer et al., 1987). N. Khan et al. (2010) justified the relation of value equity drivers (price and quality), commitment, satisfaction and attitude to communication with loyalty intentions in the banking industry and argued that the dimension of relationship value is missing in the scaling of the influence of value on loyalty intentions. L. J. C. Fiol et al. (2011) investigated price, convenience, switching costs, product quality, service quality and service staff quality as value equity factors; image and reputation were chosen as the attributes of social value, whereas experience, personal attention and relationship value were chosen as the components of emotional value.

\section{Loyalty and Brand Equity}

The concept of loyalty changed along with the prevailing approaches in marketing theory. Early research into brand loyalty was aimed to study loyalty as the behavioural expression and define loyalty antecedents. Brand loyalty was explained as a numeric or percent value in the category of specific brand purchases or the consistency of brand choices of repeat purchases (Jacoby, 1971). Later, researchers started applying the customer loyalty classification framework developed by A. Dick \& K. Basu (1994) to distinguish brand loyalty from repeated brand purchases. Cognitive and affective antecedents were undoubtedly necessary for brand loyalty building. On other hand, emotional aspects of customer attitude have a significant effect on brand loyalty (Morison \& Crane, 2007).

Around 1990s the researchers started analysing the concept of brand equity (Keller, 1993). Brand equity is understood as the outcome of brand marketing efforts by comparing it with the outcome of brand absence (Aaker, 1996). Brand equity is of utmost importance on the banking market because in recent years the differentiation of finance services has become less possible. Finance services have become intangible and easily copyable; the majority of commercial banks manage to offer similar new products to the market at almost the same time (Levy, 1996). The brand equity on the retail banking market is pre-conditioned by two determinants (1) attitude toward brand (Rust et al., 2004; Johnson 
et al., 2006; Holehonnur et al., 2009) and (2) attitude toward company (Fombrun \& van Riel, 1997; Fombrun \& Rindova, 1998; Silver \& Berggren, 2010).

It can be stated that branding approach influenced the analysis of loyalty concept and loyalty studies: the analysis of loyalty antecedents (Jacoby, 1971; Dick \& Basu, 1994) evolved into the studies of brand equity as one of the antecedents of loyalty (Vogel et al., 2008; Holehonnur et al., 2009).

\section{Loyalty and Value Equity}

The roots for studying value equity as antecedent of loyalty come from service quality theory. It could be stated that customer perceived quality is one of the most frequently analyzed antecedents of loyalty. In conceptualizing the service quality model A. Parasuraman et al. (1985) identified ten key antecedents of quality: reliability, responsiveness, competence, accessibility, courtesy, communication, credibility, security, understanding the customer and tangibility. C. Grönroos (1990) analyses service quality as a construct with two components - technical (or outcome) and functional (or process). The technical component of quality shows the outcome obtained by the customer by using the service whereas the functional component reflects the relation between the customer and the organization and the assessment of the place (or environment) where the service was provided (Grönroos, 1990). Tangible and intangible constituents of quality were important in evaluating either customer view of an organization or trust (Doney \& Cannon, 1997; Garbarino \& Johnson, 1999; Singh \& Sirdeshmukh, 2000).

It should be noted that irrespective of numerous studies the researchers have not reached a consensus as to variety of antecedents of the loyalty construct. There are controversial data about the link of primary level antecedents with loyalty or secondary level antecedents. Some authors proved that price as a primary level antecedent influences customer satisfaction and has an effect on loyalty through satisfaction (Bolton \& Lemon, 1999); other authors argue that price has an effect on trust and loyalty (Singh \& Sirdeshmukh, 2000). There is no consensus as to the components of the primary level antecedents of customer loyalty (e.g. functional quality of service) although there are no doubts that technical quality has a great influence on quality and loyalty (Grönroos, 1990; Rust \& Oliver, 1994).

Based on literature review and recommendations for the study in banking sector we selected components of the value equity as (1) price (Rust et al., 2004; Vogel et al., 2008; Holehonnur et al., 2009), (2) empathy, (3) assurance (Kwan \& Hee, 1994; Baumann et al., 2007; Sanayei et al., 2008; Mengi, 2009; Lo et al., 2010) and (4) convenience (Rust et al., 2004; Vogel et al., 2008; Holehonnur et al., 2009).

Based on literature review, in order to define the impact of value equity and brand equity on loyalty in retail banking sector, we hypothesize the followings:

$\mathrm{H} 1$ : Value equity is a direct predictor of retail banking customer loyalty.

$\mathrm{H} 2$ : Brand equity is a direct predictor of retail banking customer loyalty.

\section{Research Methodology}

To verify the impact of value equity and brand equity on loyalty, the retail customers of the Lithuanian commercial bank were questioned under a standardized questionnaire. The sample group was 
the local bank customers from five biggest cities in Lithuania. The totals of 1350 questionnaires were distributed and 1111 questionnaires were coded for the data analysis.

To ensure the face and content validity, the questionnaire was reviewed by five academicians and five banking professionals and pilot testing has been conducted on 20 samples. The questionnaire consists of two sections. The first section is to evaluate value equity (price, convenience, assurance, empathy), brand equity (attitude toward brand, attitude toward organization), and loyalty.

The indicators of value equity (price, assurance and empathy) were measured with twelve items adopted from S. Putrevu \& T. Ratchford (1997), A. Parasuraman et al. (1988), J. G. Barnes \& D. M. Howlet (1998) and J. C. F. Roig et al. (2006). The indicator of convenience with four items was created by authors.

In terms of brand equity it proposed to compose of two indicators (attitude toward brand and attitude toward organization) with five items. These items were adopted from W. Boulding \& A. Kirmani (1998) and J. H. Washburn \& R. E. Plank (2002). The loyalty measures include recommending the bank to others and intentions to be loyal with four items adopted from V. A. Zeithaml et al. (1996). Respondents rated all measures on a Likert scale ranging from 1 (strongly disagree) to 7 (strongly agree).

The second section in questionnaire is about the demographic background of the respondents. Among the analyzed samples $53,2 \%$ of respondents were female, $65,1 \%$ had bachelor degree of education and 55,3\% were married (see Table 1).

Sample Profile

\begin{tabular}{|l|l|c|}
\hline \multicolumn{2}{|c|}{ Characteristics of respondents } & Percentage \\
\hline \multirow{5}{*}{ Relationship duration } & Up to 1 year & 12,5 \\
\cline { 2 - 3 } & From 1 to 3 years & 26,6 \\
\cline { 2 - 3 } & From 3 to 5 years & 27,1 \\
\cline { 2 - 3 } & From5 to 10 years & 24,4 \\
\cline { 2 - 3 } & More than 10 years & 9,4 \\
\hline \multirow{5}{*}{ Education } & Secondary education & 13,8 \\
\cline { 2 - 3 } & Higher/ vocational & 21,1 \\
\cline { 2 - 3 } & Bachelor's degree & 65,1 \\
\hline \multirow{5}{*}{ Age } & Unmarried & 23,3 \\
\cline { 2 - 3 } & Married & 55,3 \\
\cline { 2 - 3 } & Divorced & 17,1 \\
\cline { 2 - 3 } & Partners & 4,3 \\
\hline & $18-24$ years & 9,0 \\
\cline { 2 - 3 } & $25-35$ years & 24,3 \\
\cline { 2 - 3 } & $36-45$ years & 26,5 \\
\cline { 2 - 3 } & $46-55$ years & 20,1 \\
\cline { 2 - 3 } & $56-65$ years & 14,0 \\
\cline { 2 - 3 } & More than 66 years & 6,1 \\
\hline \multirow{5}{*}{ Gender } & Male & 53,2 \\
\cline { 2 - 3 } & Female & \\
\hline
\end{tabular}


In terms of relationship duration with the bank $12,5 \%$ of respondents are the customers of the bank up to 1 year, 26,6\% from 1 to 3 years, 27,1\% from 3 to 5 years, $24,4 \%$ from 5 to 10 years and 9,4\% more than 10 years.

\section{Results}

\section{Factor analysis}

The factor analysis was conducted to identify value and brand equity scales. The appropriateness of factor analysis was determined by the Kaiser-MeyerOlkin measure of sampling adequacy and Bartlett's test of sphericity. According to J. F. Hair et al. (2006), convergent validity of measurement model was assessed by checking factor loading, average variances extracted and construct reliability. Cronbach alpha coefficients (a) were computed to quantify the scale reliabilities of the factors identified. The reliability assessment of each factor ranged from 0.69 to 0.85 (according to R. P. Bagozzi \& Y. Yi (1998) construct must meet the minimum reliability of $0.60)$. It could be stated that according to the requirements value equity and brand equity impact on loyalty instrument possesses acceptable reliability (as presented in Table 2).

Results showed that the relationship between questionnaire statements and the factors as well as their theoretical grouping were valid. Factor loading was used for including items for the factor and the Eigen value criterion (latent root criterion) was used for factor inclusion. The lowest factor loading is 0.63 while the highest factor loading is 0.94 and the lowest Eigen value accounts for 1.78 .
Results of factor analysis showed that primary factors derived are labeled as price (Eigen value $=2,624, \alpha=0,846$ ), assurance (Eigen value $=2,361, \alpha=0,754$ ), empathy (Eigen value $=3,247, \alpha=0,787$ ), convenience (Eigen value $=2,420$, $\alpha=0,837$ ), attitude toward brand (Eigen value $=1,913, \alpha=0,697)$ and attitude toward organization (Eigen value $=1,778$, $a=0,874$ ).

After the first factor analysis, another factor analysis was run to check if components identified for the first time in previous factor analysis can be clustered together under value equity and brand equity antecedents (as presented in Table 3).

Based on the results second-order factors derived are labeled as value equity (Eigen value $=2,756, \alpha=0,849$ ) and brand equity (Eigen value $=1,750$, $\alpha=0,857)$.

\section{Partial Least Square}

Partial Least Square (PLS) method was utilised in identifying the relationship between loyalty and value equity as well as brand equity. PLS is the most appropriate method for conducting this type of study on loyalty (Ryan et al., 1999). According to Wold (1982), PLS method integrates some aspects of principal components analysis and multiple regression.

According to standardized coefficients and $p$ value both value equity $(\beta=0,668$, $\mathrm{t}=28,89, \mathrm{p}<0,001)$ and brand equity $(\beta=0,785, t=41,57, p<0,001)$ have $a$ positive effect on loyalty. Therefore, hypotheses $\mathrm{H} 1$ and $\mathrm{H} 2$ are supported. Thus, it can be stated that PLS suits well for predicting effects of value equity and brand equity on loyalty. 
Factor Analysis for Customer Perceived Value Determinants

Table 2

\begin{tabular}{|c|c|c|c|c|}
\hline Items & $\begin{array}{c}\begin{array}{c}\text { Factor } \\
\text { loading }\end{array} \\
\end{array}$ & $\begin{array}{l}\text { Eigen } \\
\text { value }\end{array}$ & \begin{tabular}{|c|} 
Explained \\
variances
\end{tabular} & $\begin{array}{l}\text { Cronbach } \\
\text { alpha }(\alpha)\end{array}$ \\
\hline Price (primary factor) & & 2,624 & 65,59 & 846 \\
\hline The payment of interest / commission is fully justified & ,765 & & & \\
\hline The service is good for the expense it causes me & ,799 & & & \\
\hline The total cost that it causes me is reasonable & ,864 & & & \\
\hline The bank has the lowest cost for a full service & 808 & & & \\
\hline Assurance (primary factor) & & 2,361 & 59,02 & ,754 \\
\hline Employees here are consistently courteous with me & 829 & & & \\
\hline $\begin{array}{l}\text { The installations of bank favor the confidentiality and the } \\
\text { privacy of dealings }\end{array}$ & 810 & & & \\
\hline I feel safe in my transactions with the bank & ,785 & & & \\
\hline I will not get better service at another bank & 634 & & & \\
\hline Empathy (primary factor) & & 3,247 & 81,18 & ,787 \\
\hline The bank has employees who give me personal attention & ,903 & & & \\
\hline My dealings here are very pleasant & ,919 & & & \\
\hline $\begin{array}{l}\text { The level of quality here is acceptable in comparison with } \\
\text { other banks }\end{array}$ & ,875 & & & \\
\hline The results of the service received at the bank were as expected & 907 & & & \\
\hline Convenience (primary factor) & & 2,420 & 60,49 & 837 \\
\hline The bank internet banking system is user-friendly & ,770 & & & \\
\hline $\begin{array}{l}\text { The facility of bank have convenient parking place available } \\
\text { for its customers }\end{array}$ & 808 & & & \\
\hline The facility of bank is in an easily accessible location & 824 & & & \\
\hline $\begin{array}{l}\text { The bank has convenient territorial customer service network } \\
\text { and ATM network }\end{array}$ & ,704 & & & \\
\hline Attitude toward brand (primary factor) & & 1,913 & 63,77 & ,697 \\
\hline The brand of the bank is superior to other brands & ,708 & & & \\
\hline I feel good about being a client of the bank & 846 & & & \\
\hline $\begin{array}{l}\text { Even if another bank brand has same features as the bank, I } \\
\text { would prefer the bank }\end{array}$ & 834 & & & \\
\hline Attitude toward organization (primary factor) & & 1,778 & 88,90 & ,874 \\
\hline The reputation of the bank is high & 943 & & & \\
\hline The bank is well-established & 943 & & & \\
\hline
\end{tabular}

Secondary Factors of Customer Perceived Value

\begin{tabular}{|c|c|c|c|c|}
\hline Items & $\begin{array}{c}\text { Factor } \\
\text { loading }\end{array}$ & Eigen value & $\begin{array}{c}\text { Explained } \\
\text { variances }\end{array}$ & $\begin{array}{c}\text { Cronbach } \\
\text { alpha }\end{array}$ \\
\hline Value equity & & 2,756 & 69,19 & 849 \\
\hline Price & ,759 & & & \\
\hline Assurance & 911 & & & \\
\hline Empathy & 890 & & & \\
\hline Convenience & ,776 & & & \\
\hline Brand equity & & 1,750 & 87,51 & 857 \\
\hline Attitude toward brand & ,935 & & & \\
\hline Attitude toward organization & ,935 & & & \\
\hline
\end{tabular}




\section{Discussion}

This study stated that brand equity and value equity impact loyalty. It also produced support for the conceptualization of loyalty based on cognitive and affective antecedents (Khan et al., 2010). Thus, the present study confirms that retail bank customers' perceived value includes (1) functional aspects of value as price, convenience, assurance and empathy and (2) aspects of brand appraisal as attitude toward brand and attitude toward organization.

The study results disclosed that brand equity would predict customer loyalty and value equity would predict loyalty. The results of this study suggest that brand equity is more significant in predicting customer loyalty than value equity. Therefore retail banking managers are offered appropriate guidelines for enhancing both brand and value equity to increase customer loyalty. Marketing managers should take into consideration the study finding that focusing their efforts on brand equity will boost loyalty more than focusing on value equity, although both values are essential in maintaining retail banking customer loyalty.

On the other hand, the results are inconsistent with the research of V. Vogel et al. (2008). As past research shows that value equity is of primary importance of loyalty intentions and future sales in retail market (Vogel et al., 2008), our results states that offering low prices, improving convenience and quality of finance services is not as important while maximizing loyalty in banking sector. Banks must focus the attention on developing and maintaining favourable brand equity. It is strongly recommended that bank managers should improve brand equity by maintaining superiority of the bank's brand, making clients feel good about being a client of the bank as well as maintaining high reputation of the bank and customer opinions about the bank as well established one in the field. Furthermore, contradictory to the findings of A. Holehonnur et al. (2009) the findings of this study prove that convenience has significant role with regards to value equity.

The findings of our study must be viewed in the light of some limitations. We analyzed the data from respondents who are the current customers of one commercial bank. Thus, caution must be carrying out while generalizing findings to other industries or other customer groups (potential customers). Hence, future research should look into different industry in order to generate more insights for the brand equity and value equity constructs and their effects on loyalty.

\section{References}

1. Aaker, D. A. (1996). Measuring brand equity across products and markets. California Management Review, 38, 102-120.

2. Alrubaiee, L., Al-Nazer, N. (2010). Investigate the impact of relationship marketing orientation on customer loyalty: the customer's perspective. International Journal of Marketing Studies, 2 (1), 155-174.
3. Bagozzi, R. P., Yi, Y. (1988). On the evaluation of structural equation models. Journal of the Academy of Marketing Science, 16(1), 74-94.

4. Barnes, J. G., Howlett, D. M. (1998). Predictors of equity in relationships between financial services providers and retail customers. International Journal of Bank Marketing, 16 (1), 15-23. 
5. Baumann, C., Burton, S., Elliot, G., Kehr, H. M. (2007). Prediction of attitude and behavioural intentions in retail banking. International Journal of Bank Marketing, 25 (2), 102-116.

6. Beerli, A., Martin, J. D., Quintana, A. (2004). A model of customer loyalty in the retail banking market. European Journal of Marketing, 38 (1/2), 253-275.

7. Bergeron, J. Roy, J., Fallu, J. (2008). Pleasantly surprising clients: a tactic in relationship marketing for building competitive advantage in the financial services sector. Canadian Journal of Administrative Sciences, 25 (3), 171-184.

8. Bolton, R. N., Lemon, K. N. (1999). A dynamic model of customers' usage of services: usage as an antecedent and consequence of satisfaction. Journal of Marketing Research, 36 (2), 171-186.

9. Boulding, W., Kirmani, A. (1993). A consumerside experimental examination of signaling theory: do consumers perceive warranties as signals of quality? Journal of Consumer Research, 20, 111-123.

10. Clarke, R. D., Garderner, E. P. M., Feeney, P., Molyneux, P. (1988). The genesis of strategic marketing control in british retail banking. The International Journal of Banking Marketing, 6 (2), 5-19.

11. Dibb, S., Meadows, M. (2004). Relationship marketing and CRM: a financial services case study. Journal of Strategic Marketing, 12, 111-125.

12. Dick, A., Basu, K. (1994). Customer loyalty: toward an integrated conceptual framework. Journal of the Academy of Marketing Science. 22 (2), 99-113.

13. Doney, P. M., Cannon, J. P. (1997). An examination of the nature of trust in buyer-seller relationships. Journal of Marketing, 61, 35-51.

14. Dwyer, F. R., Schurr, P. H., Oh, S. (1987). Developing buyer seller relations. Journal of Marketing, 51 (2), 11-28.

15. Ferguson, R., Hlavinka, K. (2007). Choosing the right tools for your relationship banking strategy. Journal of Consumer Marketing, 24 (2), 110117.

16. iol, L. J. C., Tena, M. A. M., Garcia, J. S. (2011). Multidimensional perspective of perceived value in industrial clusters. Journal of Business \& Industrial Marketing, 26 (2), 132-145.

17. Fombrun, C. J., Rindova, V. P. (1998). Reputation management in global 1000 firms: A benchmarking study. Corporate Reputation Review, 1 (3), 205-214.
18. Fombrun, C. J., van Riel, C. B. M. (1997). The reputational landscape. Corporate Reputation Review, 1, 5-15.

19. Foo, M-H., Douglas, G., Jack, M. A. (2008). Incentive schemes in the financial services sector. International Journal of Bank Marketing, 26, 2, 99-118.

20. Galletly, E. (2009). Digitisation to colaboration: realizing customer value in transaction banking. The art and science of maintaining the right balance between technology and business relationships. Finance Asia, 26-27.

21. Garbarino, E., Johnson, M. S. (1999). The different roles of satisfaction, trust and commitment in customer relationships. Journal of Marketing, 63 (2), 70-87.

22. Garderner, E., Howcroft, B., Williams, J. (1999). The new retail banking revolution. The Service Industries Journal, 19 (2), 83-100.

23. Gounaris, S. P., Tzempelikos, N. A., Chatzipanagiotou, K. (2007). The relationships of customer-perceived value, satisfaction, loyalty and behavioral intentions. Journal of Relationship Marketing, 6 (1), 63-87.

24. Grönroos, C. (1990). Service Management and Marketing: Managing the Moments of Truth in Service Competition. Lexington, MA Lexington Books.

25. Hair, J. F., Black, B., Bablin, B., Anderson, R. E., \& Tatham, R. L. (2006). Multivariate data analysis. $6^{\text {th }}$ edition. Prentice Hall.

26. Holehonnur, A., Raymond, M. A., Hopkins, C. D., Fine, A. C. (2009). Examining the customer equity framework from a consumer perspective. Brand Management, 17 (3), 165-180.

27. Huber, F., Herrmann, A., Henneberg, C. (2007). Measuring customer value and satisfaction in services transactions, scale development, validation and cross-cultural comparison. International Journal of Consumer Studies, 31, 554-564.

28. Izquierdo, C. C., Rodríguez, S., San José, R. (2006). Customers' perception of value in financial services relationships: a Spanish case. Journal of International Consumer Marketing, 19 (1), 57-77.

29. Jacoby, J. (1971). A model of multi-brand loyalty. Journal of Advertising Research, 11 (3), 25-31.

30. Johnson, M. D., Herrmann, A., Huber, F. (2006). The evolution of loyalty intentions. Journal of Marketing, 70, 122-132.

31. Keller, K. L. (1993). Conceptualizing, measuring, managing customer-based brand equity, Journal of Marketing, 57, 1-22. 
32. Khan, N., Kadir, S. L. S. A., Wahab, S. A. (2010). Investigating structure relationship from functional and relational value to behavior intention: the role of satisfaction and relationship commitment. Intemational Joumal of Business and Management, 5 (10), 20-36.

33. Kwan, W., Hee, T. J. (1994). Measuring service quality in Singapore retail banking: a gap analysis and segmentation approach. Singapore $\mathrm{Ma}$ nagement Review, 16 (2), 1-24.

34. Lee, M., Cunningham, L. F. (2001). A cost/benefit approach to understanding service loyalty. Journal of Services Marketing, 15 (2), 113-30.

35. Levy, M. (1996). Current accounts and baked beans: Translating FMGC principles to the financial sector. Journal of Brand Management, 4 (2), 95-99.

36. Lo, L. K., Mahamad, O., Ramayah, T., Mosahab, R. (2010). The impact of service quality on customer loyalty: A study of banks in Penang, Malaysia. International Journal of Marketing Studies, 2 (2), 57-66.

37. Mengi, P. (2009). Customer satisfaction with service quality: An empirical study of public and private sector banks. IUP Journal of Management Research, 8 (9), 7-17.

38. Morison, S., Crane, F. G. (2007). Building the service brand by creating and managing an emotional brand experience. Brand Management, 14 (5), 410-421.

39. Panther, T., Farquhar, J. D. (2004). Consumer responses to dissatisfaction with financial service providers: an exploration of why some stay while others switch. Journal of Financial Services Marketing, 8 (4), 343-53.

40. Parasuraman, A., Berry, L. L., Zeithaml, V. A. (1998). SERVQUAL: a multi-item scale for measuring consumer perceptions of service quality. Journal of Retailing, 64 (1), 12-40.

41. Parasuraman, A., Zeithaml, V. A., Berry. L. L. (1985). A conceptual model for service quality and its implications for future reaearch. Journal of Marketing, 49, 41-50.

42. Putrevu, S., Ratchford, T. (1997). A model of search behavior with an application to grocery shopping. Journal of Retailing, 73, (4), 463-468.
43. Reinartz, W. J., Kumar, V. (2000). On the profitability of long-life customers in a noncontractual setting: an empirical investigation and implications for marketing. Journal of Marketing, 4, 17-35.

44. Roig, J. C. F., Garcia, J. S., Tena, M. A. M. Monzonis, J. L. (2006). Customer perceived value in banking services. International Journal of Bank Marketing, 24 (5), 266-283.

45. Rust, R. T., Lemon, K. N., Zeithaml, V. A. (2004). Return on marketing: using customer equity to focus marketing strategy. Journal of Marketing, 68, 109-127.

46. Ryan, M. P., Ryaner, R., Morrison, A. (1999). Diagnostic customer loyalty drivers. Marketing Research, 11(2), 19-26.

47. Sanayei, A., Moeini, H., Shafiei, M. (2008). Relationship between service quality, customer satisfaction and customer loyalty in Shiraz banking system. Journal of International Marketing \& Marketing Research, 33 (1), 31-44.

48. Silver, L., Berggren, B. (2010). The close relationship strategy - corporate brand development in banking. Brand Management, 17 (4), 289300.

49. Singh, J., Sirdeshmukh, D. (2000). Agency and trust mechanisms in consumer satisfaction and loyalty judgments. Journal of the Academy of Marketing Science, 28 (1), 150-167.

50. Sweeney, J. C., Soutar, G. N. (2001). Consumer perceived value: The development of a multiple item scale. Journal of Retailing, 77, 203-220.

51. Vogel, V., Evanshitzky, H., Ramaseshan, B. (2008). Customer equity drivers and future sales. Journal of Marketing. 72, 98-108.

52. Washburn, J. H., Plank, R. E. (2002). Measuring brand equity: An evaluation of a consumerbased brand equity scale. Journal of Marketing Theory and Practice, 10, 46-62.

53. Wold, H. (1982). Soft modeling: The basic design and some extensions. In K. G. Jöreskog \& H. Wold (Eds.), Systems under indirect observations, 1-54. Amsterdam: North- Holland.

54. Zeithaml, V. A., Berry, L. L., Parasuraman, A. (1996). The behavioral consequences of service quality. Journal of Marketing, 60 (2), 31-46.

The paper submitted: January 01, 2013

Prepared for publication: October 28, 2013 
Neringa IVANAUSKIENĖ, Viltė AURUŠKEVIČIENĖ

\section{FUNKCINĖS IR PREKĖS ŽENKLO VERTĖS ITAKA LOJALUMUI: EMPIRINĖ STUDIJA MAŽMENINĖS BANKININKYSTĖS RINKOJE}

\section{S a n t r a u a}

Mokslinè klientų lojalumo sampratos analizè leidžia teigti, kad lojalumo teorija yra neatsiejama nuo paslaugos kokybès teorijos ir prekès ženklo teorijos įtakos, o lojalumo veiksnių tyrimai, nepaisant jų gausos, vis dar neatskleidžia visaapimančio požiūrio ì lojalumo priežastingumo ryšius. Integruoto požiūrio nebuvimas sąlygoja nepakankamą lojalumą lemiančių veiksnių analizès lygị.

Straipsnyje tiriama mokslinè problema kyla iš to, kad ligšioliniuose tyrimuose pagrindiniai, lojalumą lemiantys vertès veiksniai - funkcinè verte ir prekès ženklo vertė - nebuvo išsamiai nagrinèti. Akivaizdu, kad šie veiksniai gali reikštis vienu metu ir kartu gali lemti lojalumą kitaip nei kiekvienas iš jų, veikdamas izoliuotai. Verté, kaip vienas svarbiausių lojalumą lemiančių veiksnių, yra daugiadimensinis konstruktas (Sweeney ir Soutar, 2001). Dauguma autorių empiriniuose tyrimuose naudojo skirtingas vertès dedamąsias, nors dažniausiai tirta funkcinès, emocinès ir socialinès vertés dedamųjų svarba (Sweeney ir Soutar, 2001; Roig ir kt., 2006; Izquierdo ir kt., 2006; Moliner ir kt., 2006). Mokslinès literatūros analizè patvirtina, kad nepaisant atliktų teorinių bei empirinių tyrimų gausos, lojalumas dar analizuojamas fragmentiškai. Tai pagrindžia tolesnių tyrimų šioje srityje poreikį.

Mokslinè problema - kaip funkcinè vertè ir prekès ženklo vertè veikia mažmeninès bankininkystès klientų lojalumą? Mokslinio tyrimo objektas - funkcine ir prekès ženklo vertemis pagrịstas lojalumas. Tyrimo tikslas - nustatyti funkcinès ir prekès ženklo verčių ittaką lojalumui mažmeninès bankininkystès klientų tarpe.
Funkcinès ir prekès ženklo verčiu ịtaka pagrịsto lojalumo tyrimui pasirinktas kiekybinis tyrimas. Kiekybinio tyrimo duomenys surinkti naudojant apklausos metodą, tyrimo duomenys apdoroti pasitelkus SPSS for Windows 19.0 statistinį duomenų apdorojimo paketą. Atliktos faktorinè ir dalinès mažiausių kvadratų regresijos (plg. angl. Partial Least Squares) analizès.

Faktorinès analizès metodu patvirtintas funkcinès ir prekès ženklo verčiu ịtakos pagrịsto lojalumo prasmingumas ir dimensiškumas, empirinio tyrimo skalių patikimumas bei atitikimas metodologinems tinkamumo normoms.

Taikant dalinès mažiausių kavadratų regresijos metodą nustatyta, kad stipriausias ryšys yra tarp prekès ženklo vertès $(B=0,784, p<0,001)$ ir lojalumo, tuo metu, kai funkcinès vertès ryšys su lojalumu silpnesnis $(B=0,667, p<0,001)$. Tyrimo dumenys leidžia teigti, kad bankui orientuojant savo rinkodaros pastangas i prekés ženklo vertés didinimą, šio veiksnio išraiškos padidèjimas leistų padidinti lojalumą daugiau nei didinant funkcinès vertès veiksnio išraišką.

Remiantis apibrežtumo ir standartizuotųju koeficientų igytomis reikšmėmis nustatyta, kad prekès ženklo vertẻ turi stipresnę įtaką lojalumui nei funkcinè vertè. Galima teigti, kad ateityje bankai, siekdami didinti klientų lojalumą, didžiausią demeși turi skirti prekès ženklo vertès didinimui, tuo metu, kai funkcinès vertès didinimas turi mažesnę itaką formuojant kliento lojalumą. Remiantis tyrimo duomenimis straipsnyje pateikiamos rekomendacijos mažmeninès bankininkystės rinkodaros specialistams. 